${ }^{4}$ Suggate, R. P., N.Z. Jl Geol. Geophys., 16, 172 (1973).

${ }^{5}$ Hayes, D. E., and Connolly, J. R., Antarctic Oceanology II: the Austra Iian-New Zealand Sector, Antarctic Res. Ser., 19, 125 (1972).

' Connolly, J. R., N.Z. Jl Geol. Geophys., 12, $310(1969)$.

\section{Red Sea spreading}

GIRDLER and Styles ${ }^{1}$ cite geological evidence $^{2}$ from the Gulf of Suez area favouring the idea that a Carboniferous Red Sea depression existed. Various views have been put forward concerning the age of the Suez rift structures ${ }^{3-5}$. Some authorities believe block faulting and rifting does not predate Oligocene ${ }^{6}$; others have isopached a post-crystalline Basement Complex to pre-Permian linear trough $^{7}$; and some believe in a Mesozoic trough $^{3}$.

Even if definite proof were available publicly of a Carboniferous trough this would not necessarily prove that a trough of this age existed in the Red Sea area, because the Suez structures are part of a failed arm system $^{8,9}$; the Red Sea structures are part of an active spreading ridge system and the Aqaba-Dead Sea structures part of an active transform system. As such the three arms have had interlinked but separate geological histories ${ }^{8}$.

There is clear evidence in the southern Red Sea area, however, of major rifting before the Early and Medial Eocene proposed by Girdler and Styles ${ }^{1}$. A pre-Mesozoic (?pre-mid Jurassic) trough some $500 \mathrm{~km}$ long; up to $150 \mathrm{~km}$ wide and containing up to $7.5 \mathrm{~km}$ of sediments in the Mandera region of Somalia extends from coastal Tanzania to Afar ${ }^{10}$.

This trough as roughly mapped intersects the Cainozoic RRR Afar junction. Some implications are: first, that the Somalia trough may be part of an older failed rrr 'Karroo' junction, with the other failed arms buried beneath the sediments of the southern Red Sea and Gulf of Aden; second, the evolution of the Cainozoic Nubian - Somalian Arabian plate relationships must be viewed with this in mind; and third, that the Mesozoic African plate may have rotated anticlockwise after the attempted 'Karroo' disruption (crustal thinning, necking, troughing and so on) so enabling the Cainozoic East African Rift to develop over the 'Karroo' mantle plume system.

ARTHUR WhITEMAN

Petroleum Exploration Studies,

Geology and Mineralogy Department,

University of Aberdeen,

Aberdeen AB9 $1 A S, U K$

1 Girdler, R. W., and Styles, P., Nature, 247, 7 (1974).

${ }^{2}$ Heybroek, F. in Salt Basins around Africa, 17 (Institute of Petroleum, 1965).

3 Said, R., The Geology of Egypt, (Elsevier, 1962).
4 Whiteman, A. J., Geol. Mag., 105, 231 (1968).

5 Whiteman, A. J., The Geology of Sudan Republic (Oxford, 1971).

6 Robson, D. A., Phil. Trans. R. Soc., A267, 48 (1970).

7 Barr, C. B., and Klitzsch, E., in Petrol. Explor. Soc. Libya 6th Annual Field Conference (1964)

8 Burke, K., and Whiteman, A. J., in Implications of Continental Drift (edit. by Tarling, D. H., and Runcorn, W. K.) 2, 735 (1973).

9 Burke, K., and Dewey, J. K., J. Geol. (1973).

10 Beltrandi, M. D., and Pyre, A., in Sedimentary Basins of the African Coast., 159 (Assoc. African Geol. Surveys, 1973),

Dr Girdler and Mr Styles replyWHITEMAN's views on the formation of the Red Sea are well known. He considers" that "downwarping has been the major force in shaping the Red Sea depression" and he objects to any major crustal separation with the evolution of oceanic crust.

His objection to a Carboniferous Red Sea Depression is puzzling since in the literature he has been an advocate of this. In the summary of his paper Formation of Red Sea Depression he states "A depression existed in the northern part of the region in Carboniferous times ... " and on p. 237 we find "In the writer's (Whiteman's) view the Red Sea has been an area of subsidence for a large part of postCambrian time." We respect that this is a view held by some geologists and mentioned it in passing ${ }^{2}$. We were careful to put a question mark ${ }^{2}$ in our Fig. 7 and it should be clear from our Figs 5 and 6 that it is unimportant to our arguments.

We have been interested in the postulated 'ancestral pre-Jurassic trough' running from the Southern Red Sea across the horn of Africa to intersect the Tanzania coast ${ }^{3,4}$ but at the moment it seems unrelated in time and space to the seafloor spreading discussed.

\section{School of Physics, \\ University of Newcastle-upon-Tyne}

1 Whiteman, A. J., Geol. Mag., 105, 231-246 (1968).

2 Girdler, R. W., and Styles P., Nature, 247, 7-11 (1974).

3 Beltrandi, M. D., and Pyre, A., in Sedimentary Basins of the African Coast. 159-178 (Assoc. African Geol. Surv. 1973).

4 Black, R., Morton, W. H., and Hailu, T., Nature, 248, 496-497 (1974).

\section{Solubility of oxygen-nitrogen mixture in water}

MAHARAJH and Walkley ${ }^{1}$ have reported that mixtures of gases containing oxygen do not behave independently when they are dissolved in water, and as a consequence Henry's law may be deviated from by as much as $30 \%$. Liss and Slater ${ }^{2}$ found that the amount of oxygen dissolved in water from an air mixture at $25^{\circ} \mathrm{C}$ and atmospheric pressure obeyed Henry's law within their experimental limits $(4 \%)$. Wilson ${ }^{3}$ has reviewed some of the various measurements of oxygen solubility in water at different partial pressures and showed that Henry's law is generally accurate in predicting the amount of gas dissolved to within a few per cent. A thermodynamic analysis ${ }^{4}$ of Maharajh and Walkley's results showed that the large negative deviation from Henry's law (maximum at about a $1: 1$ nitrogen to oxygen ratio) leads to an absurd value for the Henry's law constant.

There have been many reports of the solubility of gas mixtures in water, and in most cases these may be shown to be in agreement with Henry's law. Glasstone ${ }^{5}$, using Winkler's data ${ }^{6}$, has demonstrated that the solubilities of oxygen, nitrogen and argon each multiplied by their atmospheric partial pressure may be used to calculate the solubility of air in water to within $1 \%$. We have calculated the hypothetical solubility of an air mixture ${ }^{7}$ of oxygen, nitrogen, argon and carbon dioxide, using smoothed literature values for the solubilities of the individual gases $^{8,9}$. The resulting solubility is $4 \%$ higher than that reported by Winkler ${ }^{6}$. Behnke $^{10}$ measured the solubility of a mixture of argon and nitrogen in water, and his value is $5 \%$ above the value calculated from Henry's law and using the recommended literature values for the solubilities of argon and nitrogen ${ }^{8}$.

We have measured the solubilities in water of nitrogen, oxygen, and a mixture of oxygen $(49.5 \mathrm{~mol} \%)$ and nitrogen $(50.5 \mathrm{~mol} \%)$ at atmospheric pressure and $25^{\circ} \mathrm{C}$. The procedure used for the solubility measurements has been desscribed previously ${ }^{11}$, and the precision of these measurements is $\pm 1 \%$. The experimentally determined solubilities expressed as mole fractions (at one atmosphere partial pressure of gas) are given in Table 1.

The value predicted for the mixed gases on basis of Henry's law is $0.1711 \times$ $10^{-4}$, which is $3 \%$ lower than the experimental value (average, $0.1770 \times 10^{-4}$ ). These results are conclusive evidence that Henry's law is not deviated from

Table 1 Solubilities as mole fractions $\times 10^{4}$ Literature $^{8}$ values are given in parentheses

\begin{tabular}{llc}
\hline $\mathrm{Gas}$ & \multicolumn{1}{c}{ Experiment } & Calculated \\
$\mathrm{N}_{2}$ & 0.1166 & - \\
& $0.1166(0.119)$ & \\
$\mathrm{O}_{2}$ & 0.2261 & - \\
& 0.2251 & \\
& $0.2284(0.231)$ & \\
$\mathrm{O}_{2} / \mathrm{N}_{2}$ & 0.1775 & \\
& 0.1779 & 0.1711 \\
& 0.1757 & \\
\end{tabular}

